\title{
Advantages and disadvantages OF DISTANCE LEARNING
}

\author{
IwONA KLISOWSKA \\ Department of Promotion of Health, Faculty of Health Sciences, \\ Wrocław Medical University ul. Barta 5, 51-618 Wrocław, Poland \\ e-mail address: iwona.klisowska@umed.wroc.pl \\ ORCID: 0000-0001-6829-3880
}

\author{
Mariola SEŃ \\ Department of Promotion of Health, Faculty of Health Sciences, \\ Wrocław Medical University ul. Barta 5, 51-618 Wrocław, Poland \\ e-mail address: mariola.sen@umed.wroc.pl \\ ORCID: 0000-0002-6790-654X
}

\author{
BARBARA GRABOWSKA \\ Department of Promotion of Health, Faculty of Health Sciences, \\ Wrocław Medical University ul. Barta 5, 51-618 Wrocław, Poland \\ e-mail adres: barbara.grabowska@umed.wroc.pl \\ ORCID: 0000-0001-7466-1280
}

\begin{abstract}
Introduction. E-learning has been known and used in many countries for a long time. It is becoming more and more popular. It is a way of teaching remotely, using the latest information technology. It can be used in any age group, starting with pre-school teaching. In the era of the SARS-CoV-2 pandemic, remote learning has been mandatory due to the need to continue the teaching process whilst at the same time reducing the risk of spreading the virus. This has revealed many advantages, but also the disadvantages of this type of teaching.

Aim \& methods. The aim of the work is to change the advantages and disadvantages of remote teaching as one of the modern forms of education. The work attempts to show the problems related to the risks and difficulties associated with distance learning and the advantages of the development of information technology. We reviewed recent literature on e- learning in Poland. We supplemented it with our own observations.

Results \& Conclusions Reviewed empirical studies from Poland suggest that the main advantages of distance learning are professional development of teachers, intergenerational experience exchange, time saving, the possibility of learning at a pace adapted to the student, access to a large quantity of teaching materials as well as the development and expansion of IT infrastructure. The main disadvantages are lack of peer interactions, the need to spend a lot of time in front of the computer, lack of physical activity, difficulties in
\end{abstract}


independent assimilation of new material, lack of direct contact with the teacher, lack of computer equipment and inadequate housing conditions, lower didactic effects, social and economic exclusion.

E-Learning is an excellent form of learning, due to its many advantages such as time savings and access to a wide range of materials, but requires a lot of commitment from the lecturers to encourage students to expand their knowledge and on the part of students selfcontrol and motivation.

Keywords: distance learning, e-learning, COVID-19

\section{INTRODUCTION}

Asaresultof theCOVID-19 pandemic, many areas of lifehavebeguntofunctionin a completely different way. In the education system, the pandemic forced the introduction of entirely remote teaching in order to enable students to continue their education. Ensuring safety and health has become a priority, and remote teaching was the only way to continue the provision of education. E-learning has been known and used in many countries for a long time. It is often a term that describes remote learning and teaching with the use of modern IT technologies, as well as learning supported by electronic tools and media (Topol, 2020). It can be used in all age groups, starting from pupils receiving preschool education. Therefore, its obligatory implementation was the only right and necessary solution. However, it revealed that despite its indisputable advantages, this type of teaching had many flaws.

\section{Aims AND METHODS}

Pursuant to the Regulations of the Minister of National Education and the Minister of Science and Higher Education of 11 March 2020, from 12 March 2020 until the beginning of the summer holidays in June 2020, no traditional classes were held at Polish schools and universities. Remote teaching was re-introduced from October 2021, and ended with all students returning to school as late as in June 2021.

The aim of the paper is to present the flaws and advantages of remote teaching as one of the modern forms of education and the only form of education that has been introduced in the era of the Covid-19 pandemic. The authors of the paper attempted to present issues related to the threats and difficulties associated with remote teaching, as well as the advantages of the development of information technology.

\section{RESULTS}

Homes of school and university students had to become their primary place of education, while homes of teachers became their workplace. Not all students have access to a computer, modern information technologies and the possibility to be 
online for many hours, which marked the already-existing differences among students. The pandemic revealed numerous social inequalities, ranging from material and information resources, through knowledge, to social and economic exclusion (Jarynowski, Stochmal \& Maciejewski, 2020). For most young people, the Internet used to be a place for entertainment, communication and information seeking, not an obligatory channel for learning and communicating. Not every household had and has enough computer equipment (a PC, scanner, printer, camera, speakers, etc.) or even space for quiet work and remote learning.

In response to these difficulties, some educational institutions provided children in need with a place and a computer at the facility. As it turned out, not only the lack of equipment, but also its operation proved to be a problem, especially for younger children. For many students, it was a completely new challenge to take notes somewhere else than in their notebooks, send emails, make scans or take online tests and quizzes. At the same time, as a result of being isolated from their peers and not receiving support from a teacher, parent or an adult person as well as due to the occurring technical problems, students grew frustrated and stressed. Direct contact and relations with others constitute one of the most important needs that are necessary for proper functioning. On the other hand, the involvement of both students and teachers, constant motivation and control are also very important. In the first period of teaching, some students reportedly did not attend remote classes at all (Michalska, 2020).

The ability to study independently was very desirable during the period of remote teaching as a significant portion of educational activities depended on students themselves. Certainly, students were not the only ones who were not ready for remote education as neither were their schools and teachers. The report entitled "Badanie edukacji zdalnej w czasie pandemii" ("Remote education during the pandemic") revealed that as many as $85 \%$ of teachers had not had any experience with remote education (Buchner, Majchrzak \& Wierzbicka, 2020).

A report prepared by Plebańska, Szyller, and Sieńczewska after the end of remote teaching revealed a basic conclusion that despite feeling unprepared and lacking administrative support, teachers managed to maintain the continuity of teaching by moving the education into the digital world (Plebańska, Szyller \& Sieńczewska, 2020). Teachers and educators had very little time to extend their knowledge and improve their skills in the field of new information technologies, the use of educational platforms and preparation of online classes. Apart from conducting online classes, teachers remained in a state of constant uncertainty and needed to quickly respond to the changing guidelines of the Ministry.

During the pandemic, people involved in the education and training process played different roles, e.g. that of a student, teacher, support person, observer. According to Bożena Sieradzka- Baziur, people played one, two or even three roles in the process of remote education. In their new and varied roles, they experienced different emotions, struggled with material difficulties, and a lack of or incomplete digital competencies that undoubtedly affected the quality of remote education. Despite numerous problems, difficulties and inequalities in the access to remote teaching, education continued, and exams, tests and thesis defenses 
were still being held. It undoubtedly indicates that this method of teaching has its advantages, and shows that teachers and students were very committed, dedicated and worked hard.

During the pandemic, the family, as a group, as well as students, teachers and educators were put to a task that no one had prepared them for. It was also difficult to expect that there would be no problems with remote teaching itself and achieving satisfactory results, but also problems related to the emotional and mental sphere. Teaching that is conducted solely remotely does not satisfy the need for belonging, and some of its participants have experienced digital exclusion. The balance between work and studying and the home environment and private life was also disturbed (Sieradzka-Baziur, 2020). The COVID-19 pandemic and the related need to distance and limit contacts, significantly influenced and changed the nature of interaction between students. The research by Jarynowski et al. Presents the role of peer networks in teaching a foreign language and reflects and assesses whether students are able to create and maintain social contacts in times of distance learning. An analysis of most educational research on practical skills confirmed a decline in e-learning progress, and some pointed to regression in students. Isolation, lack of direct contacts, in education resulted in enormous psychological costs (Jarynowski, Czopek, \& Paradowski, 2021). The indicators of mental well-being among students from Wrocław also deteriorated (Wieczorek et al., 2021).] These results indicate that distance learning as the only form of learning, introduced suddenly without proper preparation and established procedures, had unintended consequences.

A study conducted by B. Jankowiak and S. Jaskulska showed that positive opinions of teachers concerned the possibility of using remote teaching at work and developing their own professional competencies. The capability of the school to provide care for students and simultaneously implement the core curriculum was viewed in the most negative light. According to teachers, differences between students were rather exacerbated than eliminated by remote teaching, which is a concerning phenomenon (Jankowiak \& Jaskulska, 2020).

However, certain positive outcomes of remote education can also be observed in the period of obligatory remote teaching and the difficult circumstances of a health emergency, e.g. the development of digital competencies of many teachers, the development and expansion of the IT infrastructure, learning about new technologies or providing students with computer equipment. There are undoubtedly more advantages, such as saving the time spent commuting and the costs related thereto, adjusting the pace of learning to each student, although this applies to a greater extent to courses and training rather than typical classes. The possibility of accessing the platform at all times, regardless of whether someone is on sick leave, in quarantine or travelling, is certainly a huge advantage. According to students who participated in the Izabela Kochan's study, advantages of remote education included the easiness of obtaining positive grades and the possibility to prepare for, for example, the matura exam as well as aspects completely unrelated to education, namely the possibility of getting more sleep in the morning, more freedom and more free time. According to students, an excessive amount of material and 
tasks to be completed as well as the lack of contact with teachers and friends constituted flaws of remote education.

\section{SUMMARY}

Due to its numerous advantages, such as the possibility to save time as well as the access to a wide range of materials, eLearning constitutes an excellent form of education, however, it requires great involvement on the part of teachers to encourage students to extend their knowledge, as well as self-control and motivation on the part of students.

Even though it has its flaws, it seems to be the only right solution in the era of the pandemic. Problems related to this type of teaching arose due to the lack of preparation of students and teachers as well as the lack of time to prepare classes.

The main negative factor was certainly the lack of tools as well as the lack of or insufficient support, which resulted in a number of challanges. The period of the pandemic should also be a time during which the Government, the Ministry and educational institutions should make efforts to ensure that all students have equal access to information technology and provide support in case remote teaching has to be continued or re-introduced.

Nevertheless, in many ways we are not prepared for a complete and permanent transition to eLearning. The traditional form of teaching is still needed because the introduction of modern technologies into education must be combined with the preparation of guidelines for their use, in order to stimulate the process of selfregulation of learning (Surma \& Kirschner, 2020).

As a result of the lack of direct contact and interactions with students, they are frequently uninterested in learning and acquiring knowledge, despite the teacher's best efforts (Kochman, 2020). The advantages of remote education and educational platforms bring clear benefits, facilitate quick and repeated access to educational materials, reducing the time needed for photocopying worksheets, handing out papers, etc. Nevertheless, it requires preparation of classes, just as in the case of the traditional form of teaching. There are many positive and negative opinions of teachers, students and parents regarding the time of the pandemic and the introduction of remote teaching. It depends on the situation, the role in which a given person found himself or herself, and also on the time of its expression. This is certainly the time to prepare for changes in the field of education.

\section{REFERENCES}

[1] Buchner, A., Majchrzak M., Wierzbicka M., (2020). Zdalna edukacja podczas pandemii [Remote education during the pandemic], Retrieved 4 July 2020, from https://centrumcyfrowe.pl/edukacja-zdalna.

[2] Jankowiak, B., Jaskulska, S., (2020). Dobrostan nauczycieli i nauczycielek a ich postawy wobec kształcenia na odlegtość w czasie pandemii COVID-19 [The well-being of teachers and female teachers and their attitudes towards distance education during the COVID19 pandemic], Przeglad Pedagogiczny,1, 219-232. 
[3] Jarynowski, A., Stochmal, M., Maciejewski, J., (2020). Przegląd i charakterystyka prowadzonych w polsce badań na temat społecznych uwarunkowań epidemii COVID-19 w jej początkowej fazie [a review of studies of social background During the first phase of the COVID-19 epidemic in poland], Bezpieczeństwo Obronność Socjologia, 13(14), 38-87.

[4] Jarynowski, A., Czopek, K. \& Paradowski, M.B. (2021). Jak interakcje między uczniami pomagają w przyswajaniu języka obcego. Implikacje dla doby pandemii. [How student interactions facilitate second language acquisition. Corollaries for times of the pandemic], Acta Neophilologica, XXIII, (2).

[5] Kochman, I. (2020). Nauczanie zdalne w opinii uczniów szkół średnich w czasie trwania pandemii COVID-19 [Distance Learning in the opinion of high school students during a pandemic COVID-19], Studia Edukacyjne, 59.

[6] Michalska, S., (2020). Szkoła wiejska w czasie pandemii [Village school during a pandemic], Wieś i Rolnictwo, 3(188).

[7] Plebańska, M., Szyller, A., Sieńczewska, M., (2020). Raport - edukacja zdalna w czasachCovid-19 Podsumowanie wyników badania Wydziatu Pedagogicznego Uniwersytetu Warszawskiego [Report - Remote Education in the Time of Covid-19 Summary of the results of the study by the Faculty of Education of the University of Warsaw], Uniwersytet Warszawski: Warsaw.

[8] Sieradzka-Baziur, B., (2020). Uwarunkowania kształcenia zdalnego w rodzinie w dobie COVID-19 [Determinants of distance education in the family in the COVID-19 era], Horyzonty Wychowania, 19 (51).

[9] Surma, T., Kirschner, P.A., (2020). Technology enhanced distance learning should not forget how learning happens, Computers in Human Behavior, September 2020, 11.

[10] Topol, P., (2020). Metody i narzędzia kształcenia zdalnego w polskich uczelniach w czasie pandemii Covid-19 część 1, dyskusja [Methods and tools of distance learning in Polish universities during the Covid-19 pandemic part 1, discussion], Studia Edukacyjne UAM Poznań, 58.

[11] Wieczorek, T., Kołodziejczyk, A., Ciułkowicz M., Maciaszek J., Misiak B., Rymaszewska J, and Szcześniak D., (2021). Class of 2020 in Poland: Students' Mental Health during the COVID-19 Outbreak in an Academic Setting, International Journal of Environmental Research and Public Health, 18(6), 2884. 